\title{
Alteration of the counterregulatory hormones in the conscious rat after protein-energy restriction
}

\author{
T. L eon-Q uinto ${ }^{1}$, P.A dnot ${ }^{2}$, B . Portha ${ }^{1}$ \\ ${ }^{1}$ Laboratoire Physiopathologie Nutrition et CNRS URA 307, Université Paris 7, Paris, France \\ ${ }^{2}$ LIPHA S. A., Centre de Recherche de Chilly-Mazarin, Chilly-Mazarin, France
}

Summary We have recently reported that in rats submitted to protein-energy restriction early in life, an increased insulin efficiency upon the whole-body glucose utilization rate may be one reason for their chronic mild basal hypoglycaemia. However, the basis for their low plasma glucose level may also lie in the impaired activation of one or several of the counterregulatory hormones that prevent or correct hypoglycaemia. Our study was therefore designed to compare glucose counterregulatory mechanisms in restricted and control rats, both in the basal postabsorptive state and at controlled high plasma insulin level and standardized low glycaemic level (hypoglycaemic-hyperinsulinaemic glucose clamps performed in conscious rats). When tested in the basal postabsorptive state, the restricted rats exhibited prominent increases in the plasma levels of epinephrine (4.5 fold), norepinephrine (3.4 fold) and glucagon (1.7 fold). This was in the presence of significant decreases of plasma growth hormone and corticosterone levels (by 59 and $32 \%$, respectively). With respect to the responses to acute severe hypoglycaemia $(2.5 \mathrm{mmol} / \mathrm{l})$, the glucagon, epinephrine and norepinephrine plasma levels in the restricted rats increased to values similar to those in controls. Also, the corticosterone level increased but remained significantly lower $(p<0.001)$ compared to the control response. The plasma growth hormone level was not significantly affected by acute hypoglycaemia in the restricted or in the control groups. We conclude that protein-energy restriction, starting early in life in the rat, severely impairs the release of counterregulatory hormones that defend against hypoglycaemia. [Diabetologia (1997) 40: 1028-1034]

Keywords Malnutrition, protein-energy restriction, glucose counterregulatory response, glucagon, catecholamines, corticosterone, growth hormone, hypoglycaemic clamp.
Malnutrition in general, and dietary protein deprivation, in particular, are characterized by low fasting blood glucose levels despite low insulin levels in both humans and rodents [1-6]. To explain this situation, a high tissue sensitivity to insulin has been suggested [3-5]. In fact, we have recently reported that the protein-energy restricted rats present an

Received: 5 December 1996 and in revised form: 28 April 1997

Corresponding author: Professor B. Portha, Laboratoire Physiopathology of Nutrition, CNRS URA 307, Université Paris 7/D. Diderot, 2 place Jussieu, Tour 33, F-75251 Paris Cedex 05, France

A bbreviations: SRIF, somatostatin; CNS, central nervous system; GRF, growth hormone releasing factor. increased utilization of glucose in the basal postabsorptive state as well as under euglycaemic-hyperinsulinaemic conditions [5]. Similar conclusions were also reported in rats submitted to food restriction from the fetal stage [6]. Therefore heightened insulin sensitivity in the presence of lower insulin levels may be one reason for the relative hypoglycaemia. However the basis for the lower plasma glucose levels may also lie elsewhere, in the impaired activation of one or several of the counterregulatory hormones that prevent or correct hypoglycaemia. An impairment of the release and/or of the efficacy of counterregulatory systems is in fact suggested by the previous observation that exogenous insulin caused a longlasting hypoglycaemia in the protein-energy restricted rat [3]. Among the glucose counterregulatory 
factors, glucagon plays a primary role $[7,8]$. Normally, epinephrine is not considered to be critical but it becomes critical to glucose counterregulation when glucagon is deficient $[9,10]$. However growth hormone and glucocorticoids, which do not seem to play a role in defense against acute hypoglycaemia [11], have been found to be important during adaptation to prolonged hypoglycaemia, increasing glucose production and decreasing its utilization $[12,13]$. Our study was therefore designed to compare the main glucose counterregulatory factors (glucagon, epinephrine, norepinephrine, growth hormone and corticosterone) in the protein-energy restricted rat and the control rat, both in the basal postabsorptive state and at a controlled high plasma insulin level during matched-decrement in plasma glucose. For this last purpose, we performed the hypoglycaemic-hyperinsulinaemic glucose clamp technique in conscious rats [14].

\section{Materials and methods}

D iets. We used a powdered semi-synthetic standard diet containing by weight (g/100 g): $68 \%$ starch, $4 \%$ cellulose, $5 \%$ lipid (maize oil) and $15 \%$ protein (casein) and by calories $72 \%$ carbohydrate, $12 \%$ lipid and $15 \%$ protein. A powdered semisynthetic low protein diet contained by weight $(\mathrm{g} / 100 \mathrm{~g}): 78 \%$ starch, $4 \%$ cellulose, $5 \%$ lipid (maize oil) and $5 \%$ protein (casein) and by calories $83 \%$ carbohydrate, $12 \%$ lipid and $5 \%$ protein. The two diets were isoenergetic and the energy content per $100 \mathrm{~g}$ diet was 375 calories. Both diets contained $2 \mathrm{~g} /$ $100 \mathrm{~g}$ yeast, a salt mixture $(3.5 \mathrm{~g} / 100 \mathrm{~g})$ and a vitamin mixture $(2.2 \mathrm{~g} / 100 \mathrm{~g})$ as in reference [5].

A nimals. Female Wistar rats bred in our colony were weaned 28 days after birth, and from this age were fed either a standard or protein-energy restricted diet for 4 weeks onward. One member of each pair of littermates was fed ad libitum (standard diet) while daily food intake was measured, and the intake of the other member of the pair (low protein diet) was restricted to $65 \%$ of the ad libitum intake (standard diet) with the food being placed in the cage each evening ( $1 \mathrm{~h}$ before dark-cycle onset). The choice of a moderate level $(35 \%)$ of food restriction was suggested by the studies of Swenne et al. [15] and Okitolonda et al. [3] who reported that rats offered a low-protein diet after weaning, spontaneously reduced their daily food intake to $65 \%$ of the food intake of the animals fed a normal isocaloric diet ad libitum. Compulsory food restriction was necessitated by our previous observation that Wistar rats given this low protein diet ad libitum, spontaneously maintained a normal food intake [16]. Normal rats fed the standard diet ad libitum for 4 weeks were used as controls.

It is important to mention that no major alteration of the feeding pattern took place in the protein-energy restricted group since we have verified that rats had an excess of food available most of the time during the nocturnal feeding period and that the restricted rats never consumed their daily food ration in one short meal (in contrast to the findings usually reported in more severe food-restriction protocols). Since for the clamp experiments performed at 14.00 hours, food was withdrawn from the two groups of rats in the morning of the study shortly after light-cycle onset, one may therefore consider that the duration of subsequent fasting was comparable in the two groups.
After following the diets for 4 weeks, animals from each group underwent hypoglycaemic/hyperinsulinaemic clamps.

Surgical procedures. Non-fasted animals (at the age of 77.5 weeks) were anaesthetized with ketamine hydrochloride ( $95 \mathrm{mg} / \mathrm{kg}$ i.p; Imalgène, Mérieux, France). Body temperature was maintained at $37-38^{\circ} \mathrm{C}$ with heating lamps. Two polyethylene catheters (Merck-Biotrol, France) were inserted into both jugular veins and filled with polyvinylpyrrolidone $(1.7 \mathrm{~g} /$ $\mathrm{ml})$ solution. They were tunneled subcutaneously around the side of the neck, and externalized behind the head through a skin incision. After the cannula implantation, each rat was housed individually throughout the study. Only those animals which had completely recovered and showed no sign of infection within 2.5 days after surgery were used. During this time, the animals were connected to the blood sampling tubing several occasions to habituate them to the sampling procedure.

$\mathrm{H}$ yperinsulinaemic/hypoglycaemic clamp. In order to determine the hormonal responses to a severe hypoglycaemia $(2.5 \mathrm{mmol} / \mathrm{l})$, we used the hyperinsulinaemic-hypoglycaemic glucose clamp technique as adapted in conscious rats by Borg et al. [14]. Two sets of clamp experiments were performed. In the first one, the samples were used to measure the plasma epinephrine, norepinephrine and glucagon levels. The second series of clamps was performed to study growth hormone and corticosterone responses.

Studies were performed at 14.00 hours in rats fasted from 09.00 hours. Animals were connected to a Precidor pump (Infors, Basel, Switzerland) via polyethylene tubing, fully awake and freely moving about in their cages. After a 60min rest period, blood samples were drawn for measurement of basal plasma glucose, insulin $(100 \mu \mathrm{l}$ of blood), glucagon $(200 \mu \mathrm{l}$ of blood) and catecholamines (epinephrine and norepinephrine, $800 \mu$ l of blood), or growth hormone and corticosterone ( $200 \mu \mathrm{l}$ of blood). After a blood sample had been taken, an equal volume of saline was perfused to prevent hypovolaemia. Thereafter continuous infusion of insulin (Porcine monocomponent insulin Actrapid; Novo, Copenhagen, Denmark) dissolved in $0.9 \% \mathrm{NaCl}$ containing $0.2 \%$ bovine serum albumin (Sigma, St Louis, Mo., USA) was initiated and maintained for approximately $90 \mathrm{~min}$ at a constant rate of $7.2 \mathrm{nmo-}$ $1 \cdot \mathrm{kg}^{-1} \cdot \mathrm{h}^{-1}$. A variable infusion of exogenous glucose $(10 \%$ solution) was adjusted based on plasma measurements obtained at 5-min intervals to achieve the desired glucose level. Plasma glucose was allowed to fall to hypoglycaemic levels $(2.5 \mathrm{mmol} / \mathrm{l})$ and maintained there for $60 \mathrm{~min}$. Then, blood samples for measurements of glucose, insulin, glucagon, epinephrine, norepinephrine, growth hormone and corticosterone were taken. Only those studies during which the mean blood glucose level achieved during hypoglycaemia was in the range of 2.2 to $2.7 \mathrm{mmol} / \mathrm{l}$ were analysed. We could have studied the kinetic evolution of the hormonal response, but the reduced blood volume in the restricted rats (their mean body weight was only half that of the control rats), together with the necessary serial blood sampling would have added significant handling stress. Therefore we chose to measure these hormone concentrations from samples taken only at two time-points (basal state and at the end of a 60-min hypoglycaemic plateau).

A nalytical methods. Plasma glucose was determined by using a glucose analyser (Beckman, Palo Alto, Calif., USA). Plasma immunoreactive insulin was estimated using purified rat (studies in the basal state) or porcine (clamp studies) insulin as standards (Novo), antibody to mixed (porcine + bovine) insulin which cross-reacts similarly with pork and rat insulin 
Table 1. Basal levels of plasma glucose, insulin, glucagon, epinephrine, norepinephrine, growth hormone (GH) and corticosterone in conscious Wistar female rats submitted to protein-energy restriction (35\% food restriction + low protein diet) for 4 weeks

\begin{tabular}{llllllll}
\hline Rats & $\begin{array}{l}\text { Glucose } \\
{[\mathrm{mmol} / \mathrm{l}]}\end{array}$ & $\begin{array}{l}\text { Insulin } \\
{[\mathrm{nmol} / \mathrm{l}]}\end{array}$ & $\begin{array}{l}\text { Glucagon } \\
{[\mathrm{ng} / \mathrm{l}]}\end{array}$ & $\begin{array}{l}\text { Epinephrine } \\
{[\mathrm{nmol} / \mathrm{l}]}\end{array}$ & $\begin{array}{l}\text { Norepinephrine } \\
{[\mathrm{nmol} / \mathrm{l}]}\end{array}$ & $\begin{array}{l}\text { Growth hormone } \\
{[\mathrm{ng} / \mathrm{ml}]}\end{array}$ & $\begin{array}{l}\text { Corticosterone } \\
{[\mathrm{ng} / \mathrm{ml}]}\end{array}$ \\
\hline Controls & $6.2 \pm 0.2$ & $1.1 \pm 0.1$ & $124 \pm 17$ & $0.9 \pm 0.1$ & $1.9 \pm 0.2$ & $35 \pm 4$ \\
& {$[19]$} & {$[19]$} & {$[10]$} & {$[9]$} & {$[9]$} & $471 \pm 24$ \\
Protein-energy & $4.7 \pm 0.3^{\mathrm{b}}$ & $0.5 \pm 0.1^{\mathrm{b}}$ & $214 \pm 20^{\mathrm{a}}$ & $3.9 \pm 0.2^{\mathrm{b}}$ & $6.7 \pm 0.5^{\mathrm{b}}$ & $15 \pm 2^{\mathrm{b}}$ & {$[15]$} \\
restricted & {$[18]$} & {$[18]$} & {$[13]$} & {$[12]$} & {$[12]$} & {$[12]$} & $318 \pm 25^{\mathrm{b}}$ \\
\hline
\end{tabular}

Comparison was made with control rats raised in parallel and fed a standard diet ad libitum

Animals were 8 weeks old when tested. They had received either the control diet or the restricted diet from the age of Values are mean \pm SEM. The number of observations is shown in parentheses.

4 weeks (weaning).

standards, and porcine monoiodinated ${ }^{125}$ I-labelled insulin [5]. Charcoal was used to separate free from bound hormone [5]. The method allows the determination of $0.08 \mathrm{ng} / \mathrm{ml}$ with a coefficient of variation within and between assays of $10 \%$. The plasma used for the measurement of counterregulatory factors was immediately frozen in liquid nitrogen and maintained at $-80^{\circ} \mathrm{C}$ until assay. Plasma catecholamine levels were determined by high performance liquid chromatography with a C18 reversed-phase material $(150 \times 2 \mathrm{~mm})$ Beckman column packed with Ultrasphere ODS-C18 (average particle size $5 \mu \mathrm{m}$ ) and electrochemical detection (Kontron 402, St. Quentin-Yv, France) after alumina extraction. Calibration curves were made with spiked plasma. Recoveries were calculated on the basis of peak heights measured by an integrator (Shima$\mathrm{dzu}$, Kyoto, Japan). Plasma glucagon (containing $40 \mathrm{mg} / \mathrm{l}$ aprotinin as proteolytic inhibitor), growth hormone and corticosterone were measured by RIA methods using commercially available kits (Biodata, Rome, Italy; Amersham International, Les Ulis, France; ICN, Orsay, France; respectively). The sensitivities of the assays were $14.5 \mathrm{pg} / \mathrm{ml}$ for glucagon, $1.6 \mathrm{ng} / \mathrm{ml}$ for rat growth hormone and $25 \mathrm{ng} / \mathrm{ml}$ for corticosterone. The coefficients of variation within and between assays were $9 \%$ for glucagon and $7 \%$ for corticosterone. For rat growth hormone, the intra-assay coefficient of variation was $3 \%$ and the inter-assay variation was $10 \%$.

Statistical analysis. Data are given as means \pm SEM. Comparison between the groups was performed using Student's t-test for unpaired data. For all analyses, a p-value of 0.05 was considered to be significant.

\section{Results}

Characteristics of the animals. At weaning, mean body weight values were similar in each group. Thereafter female rats fed ad libitum gained weight and at the end of the experimental period (4 weeks), their mean body weight was $193 \pm 1 \mathrm{~g}(\mathrm{n}=19)$ and the mean body weight gain for these control rats was $103 \pm 5 \mathrm{~g}$ over the 4-week-period. In contrast, body weight gain was almost obtunded in the restricted female rats during the same 4-week-period $(9 \pm 1 \mathrm{~g}, \mathrm{n}=18 ; \mathrm{p}<0.001$ as compared to control group) and their mean body weight at the end of the experimental period was $100 \pm 1 \mathrm{~g}(\mathrm{p}<0.001$ as compared to control group).

In restricted rats, basal postabsorptive plasma glucose and insulin levels were both significantly $(\mathrm{p}<0.001)$ decreased (by $24 \%$ and $53 \%$, respectively), as compared to the control group levels (Table 1 ).

Counterregulatory hormones in the basal postabsorptive state. In the first set of experiments, epinephrine, norepinephrine and glucagon levels have been measured in the postabsorptive state in unanaesthetized animals. As indicated in Table 1 and when compared to control rats, restricted rats showed significant increases in plasma glucagon (1.7 fold), epinephrine (4.5 fold) and norepinephrine (3.4 fold). To eliminate the possibility that such increases are the consequence of the postoperative stress, we performed control experiments in both groups of rats, taking blood samples on days 3.5 and 5.5 after the surgery. The results were compared to those obtained 2.5 days after the surgery (Table 2). As a function of the post-surgery time, a moderate decline of the basal plasma epinephrine and norepinephrine levels was detectable (Table 2). However such a time-dependent decrease was not found to be statistically significant in either group and its extent was similar in both groups. Therefore the increased catecholamine and glucagon values in the restricted rats when compared to control rats, were related mainly to adaptation to protein-energy restriction. Basal plasma levels of growth hormone and corticosterone were found significantly blunted (by 59 and $32 \%$, respectively) in the restricted rats as compared to control rats $(p<0.001)$ (Table 1).

Counterregulatory hormones during severe hypoglycaemia. With the aim of investigating the counterregulatory response to severe hypoglycaemia in the restricted rats, plasma glucose was lowered to $2.5 \mathrm{mmol} / \mathrm{l}$. This level of glycaemia was achieved 20 $30 \mathrm{~min}$ after starting the insulin infusion and was maintained for $60 \mathrm{~min}$. At steady-state, plasma insulin rose to identical levels in both groups: $6.2 \pm 0.3$ $\mathrm{nmol} / \mathrm{l}$ for restricted rats vs $6.3 \pm 0.2 \mathrm{nmol} / 1$ for control rats (Table 3 ). Also the plasma glucose at steady-state was similar in both groups: $2.5 \pm 0.1 \mathrm{mmol} / \mathrm{l}$ for restricted rats vs $2.3 \pm 0.1 \mathrm{mmol} / \mathrm{l}$ for control rats (Table 3 ). In these experiments, the 
Table 2. Basal plasma levels of epinephrine and norepinephrine, 2.5, 3.5 and 5.5 days after surgery, in conscious Wistar female rats submitted to protein-energy restriction ( $35 \%$ food restriction + low protein diet) for 4 weeks

\begin{tabular}{|c|c|c|c|c|c|c|}
\hline \multirow[t]{2}{*}{ Rats } & \multicolumn{3}{|c|}{ Epinephrine [nmol/l] } & \multicolumn{3}{|c|}{ Norepinephrine [nmol/l] } \\
\hline & 2.5 days & 3.5 days & 5.5 days & 2.5 days & 3.5 days & 5.5 days \\
\hline Controls & $\begin{array}{l}0.9 \pm 0.1 \\
{[9]}\end{array}$ & $\begin{array}{l}0.7 \pm 0.2 \\
{[5]}\end{array}$ & $\begin{array}{l}0.7 \pm 0.2 \\
{[5]}\end{array}$ & $\begin{array}{l}1.9 \pm 0.2 \\
{[9]}\end{array}$ & $\begin{array}{l}1.8 \pm 0.2 \\
{[5]}\end{array}$ & $\begin{array}{l}1.7 \pm 0.2 \\
{[5]}\end{array}$ \\
\hline Protein-energy restricted & $\begin{array}{l}3.9 \pm 0.2^{\mathrm{a}} \\
{[12]}\end{array}$ & $\begin{array}{l}3.5 \pm 0.2^{\mathrm{a}} \\
{[6]}\end{array}$ & $\begin{array}{l}3.4 \pm 0.3^{\mathrm{a}} \\
{[6]}\end{array}$ & $\begin{array}{l}6.7 \pm 0.5^{\mathrm{a}} \\
{[12]}\end{array}$ & $\begin{array}{l}5.7 \pm 0.1^{\mathrm{a}} \\
{[6]}\end{array}$ & $\begin{array}{l}5.3 \pm 0.2^{\mathrm{a}} \\
{[6]}\end{array}$ \\
\hline
\end{tabular}

Comparison was made with control rats raised in parallel and fed a standard diet ad libitum

Animals were 8 weeks old when tested. They had received either the control diet or the restricted diet from the age of 4 weeks (weaning)

Table 3. Glucose and insulin levels and glucose kinetics during hypoglycaemic-hyperinsulinaemic clamps in conscious Wistar female rats submitted to protein-energy restriction (35\% food-restriction + low protein diet) for 4 weeks

\begin{tabular}{llllllll}
\hline Rats & $\begin{array}{l}\text { IIR } \\
{\left[\mathrm{nmol} \cdot \mathrm{h}^{-1} \cdot \mathrm{kg}^{-1}\right.}\end{array}$ & $\begin{array}{l}\text { BPI } \\
{[\mathrm{nmol} / \mathrm{l}]}\end{array}$ & $\begin{array}{l}\text { SSPI } \\
{[\mathrm{nmol} / \mathrm{l}]}\end{array}$ & $\begin{array}{l}\text { PBG } \\
{[\mathrm{mmol} / \mathrm{l}]}\end{array}$ & $\begin{array}{l}\text { SSPG } \\
{[\mathrm{mmol} / \mathrm{l}]}\end{array}$ & $\begin{array}{l}\text { SSGIR } \\
{\left[\mu \mathrm{mol} / \mathrm{min}^{2}\right]}\end{array}$ & $\begin{array}{l}\text { SSGIR } \\
{\left[\mu \mathrm{mol} \cdot \mathrm{min}^{-1} \cdot \mathrm{kg}^{-1}\right]}\end{array}$ \\
\hline Controls & 7.2 & $1.1 \pm 0.1$ & $6.3 \pm 0.2$ & $6.2 \pm 0.2$ & $2.3 \pm 0.1$ & $3.6 \pm 0.3$ & $18.7 \pm 1.5$ \\
& {$[19]$} & {$[19]$} & {$[19]$} & {$[19]$} & {$[19]$} & {$[19]$} & {$[19]$} \\
Protein-energy & 7.2 & $0.5 \pm 0.1^{\mathrm{a}}$ & $6.2 \pm 0.3$ & $4.7 \pm 0.3^{\mathrm{a}}$ & $2.5 \pm 0.1$ & $3.6 \pm 0.4$ & $35.6 \pm 3.9^{\mathrm{a}}$ \\
restricted & {$[18]$} & {$[18]$} & {$[18]$} & {$[18]$} & {$[18]$} & {$[18]$} & {$[18]$} \\
\hline
\end{tabular}

Comparison was made with control rats raised in parallel and fed a standard diet ad libitum

The animals were 8 weeks old when tested. They had received either the control diet or the restricted diets from the age of 4 weeks (weaning)

Values are mean \pm SEM. The number of observations is shown in parentheses.

${ }^{a} p<0.001$ as compared to related control group
Values are mean \pm SEM. IIR, Insulin infusion rate; SSPI, steady-state plasma insulin; BPG, basal plasma glucose; SSPG, steady-state plasma glucose; SSGIR: steady-state glucose infusion rate

${ }^{a} p<0.001$ compared to control group
Table 4. Plasma glucose, insulin, glucagon, epinephrine, norepinephrine, growth hormone and corticosterone levels during hypoglycaemic-hyperinsulinaemic clamp in conscious Wistar

\begin{tabular}{llllllll}
\hline Rats & $\begin{array}{l}\text { Glucose } \\
{[\mathrm{mmol} / \mathrm{l}]}\end{array}$ & $\begin{array}{l}\text { Insulin } \\
{[\mathrm{nmol} / \mathrm{l}]}\end{array}$ & $\begin{array}{l}\text { Glucagon } \\
{[\mathrm{ng} / \mathrm{l}]}\end{array}$ & $\begin{array}{l}\text { Epinephrine } \\
{[\mathrm{nmol} / \mathrm{l}]}\end{array}$ & $\begin{array}{l}\text { Norepinephrine } \\
{[\mathrm{nmol} / \mathrm{l}]}\end{array}$ & $\begin{array}{l}\text { Growth hormone } \\
{[\mathrm{ng} / \mathrm{ml}]}\end{array}$ & $\begin{array}{l}\text { Corticosterone } \\
{[\mathrm{ng} / \mathrm{ml}]}\end{array}$ \\
\hline Controls & $2.3 \pm 0.1$ & $6.3 \pm 0.2$ & $979 \pm 83$ & $16.1 \pm 1.1$ & $10.2 \pm 0.8$ & $33 \pm 2$ & $788 \pm 35$ \\
& {$[19]$} & {$[19]$} & {$[10]$} & {$[9]$} & {$[9]$} & {$[15]$} & $10 \pm \pm 1^{\mathrm{a}}$ \\
Protein-energy & $2.5 \pm 0.1$ & $6.2 \pm 0.3$ & $793 \pm 47$ & $16.6 \pm 1.9$ & $9.5 \pm 1.0$ & $423 \pm 47^{\mathrm{a}}$ \\
restricted & {$[18]$} & {$[18]$} & {$[13]$} & {$[12]$} & {$[12]$} & {$[12]$} & {$[13]$} \\
\hline
\end{tabular}

Comparison was made with control rats raised in parallel and fed a standard diet ad libitum

Animals were 8 weeks old when tested. They received either the control diet or the restricted diets from the age of 4 weeks (weaning).

mean glucose infusion rate in the restricted group was similar to that in the control group when expressed on a per animal basis $(3.6 \pm 0.4 \mathrm{vs} 3.6 \pm 0.3 \mu \mathrm{mol} / \mathrm{min}$, respectively). When expressed per kilogram body weight, it was found to be significantly increased in restricted rats $\left(35.6 \pm 3.9\right.$ vs $18.7 \pm 1.5 \mu \mathrm{mol} \cdot \mathrm{min}^{-1}$. $\mathrm{kg}^{-1}, \mathrm{p}<0.001$ ) (Table 3). The rate of exogenous glucose infusion required to maintain blood glucose at hypoglycaemia and at steady-state plasma insulin may be taken as an index of the effect of insulin on total-body glucose utilization. It may therefore be concluded that the insulin-stimulated total-body glucose metabolism in restricted rats is significantly higher than in control rats. This suggests that total body glucose metabolism is more responsive to insulin in female rats submitted to protein-energy restriction ( $35 \%$ food restriction + low protein diet) for 4 weeks
Values are mean \pm SEM. The number of observations is shown in parentheses.

${ }^{a} p<0.001$ compared to control group the restricted group as compared with the control group.

As shown in Table 4, during the hyperinsulinaemic-hypoglycaemic clamp, plasma levels of glucagon, epinephrine and norepinephrine in the restricted rats were not significantly different from those found in control rats. However since the levels for these counterregulatory agents were already elevated in the basal state in the restricted rats, it may be inferred that the relative epinephrine, norepinephrine and glucagon responses ( $\Delta$ increase) were markedly blunted (by 16, 60 and $32 \%$, respectively) as compared to normal responses. During the hyperinsulinaemic-hypoglycaemic clamp, corticosterone and growth hormone plasma levels were significantly 
lower (by $46 \%$ and $42 \%, p<0.001$ ) as compared to corresponding levels in the control group. The relative corticosterone response was significantly blunted (by $79 \% ; p<0.001$ ) (Table 4 ). Plasma growth hormone levels were not significantly increased by acute hypoglycaemia, either in the restricted or in the control group (Table 4).

\section{Discussion}

This study confirms previous observations that protein-energy restriction induces a drastic growth arrest in young rats. In the protein-energy restricted rats, the basal plasma insulin level was clearly decreased. In the same experimental rat model we have previously reported that the in vivo insulin response to glucose was very poor [5] in agreement with previous reports in similar models $[3,15,17,18]$, and that this impairment of insulin release was related at least in part to intrinsic abnormality(ies) of the pancreatic betacells $[5,17]$. It is also notable that in the same rat model, protein-energy malnutrition has been reported to cause a diminution of beta-cell mass [19] and that such beta-cell atrophy is a feature rather typical of protein shortage [19-22]. Under basal postabsorptive conditions and in the face of drastically lowered plasma insulin levels, protein-energy restricted rats maintained low basal plasma glucose levels. Their tolerance to intravenous glucose was maintained as shown by a normal disappearance rate ( $\mathrm{K}$ value). This last characteristic is an indication for a high sensitivity to insulin (since their $\Delta \mathrm{I}$ value was decreased by $88 \%$ during the same test) [5]. This was indeed confirmed by clamp experiments [5] showing that 1) their basal glucose utilization rate was significantly higher (2.5 fold increase) and that 2 ) the glucose utilization induced by submaximal insulin levels was significantly greater (2.6 fold increase) than in the control rats. Therefore heightened insulin sensitivity in the presence of lower insulin levels can be retained as one reason for the relative hypoglycaemia. However the basis for the lower plasma glucose levels may also lie elsewhere, in the impaired activation of one or several of the counterregulatory hormones that prevent or correct hypoglycaemia. An impairment of the release and/or of the efficacy of counterregulatory systems is in fact suggested by the previous observation that exogenous insulin caused a long-lasting hypoglycaemia in the protein-energy restricted rat [3]. Our study was therefore designed to compare glucose counterregulatory mechanisms in the proteincalorie restricted rat and the control rat, both in the basal postabsorptive state and at controlled and similar high plasma insulin levels during matched decrement in plasma glucose.

When tested in the basal postabsorptive state, the restricted rats exhibited prominent increases in the plasma levels of epinephrine (4.5 fold), norepinephrine (3.4 fold) and glucagon (1.7 fold). Secretion of epinephrine and release of norepinephrine in the rat mainly depend on sympathetic nervous system activation [22-24]. Therefore in our experiments the plasma catecholamine increase is likely attributable to an increase in sympathetic nervous activity. Indeed we have recently observed (T. Leon-Quinto, C. Magnan, unpublished data) an increase of the superior cervical ganglion firing rate in the restricted rats as compared to control rats. There are also indications in the literature for an activation of the catecholaminergic system in adult rats submitted to perinatal longlasting undernutrition or young rats fed a low-protein diet, as attested by acceleration in the norepinephrine turnover rate in brown adipose issue $[26,27]$ or an increased turnover rate of brain dopamine and norepinephrine together with a higher tyrosine-hydroxylase activity [28].

In the restricted group, the association of increased plasma catecholamine levels and high sympathetic nerve activity is likely to contribute to their basal hyperglucagonaemia, since the pancreatic alpha-cell is highly sensitive to the stimulating effect of epinephrine and norepinephrine [23-25]. In addition, many states characterized by catecholamine excess are associated with hyperglucagonaemia [2325]. Of course this possibility is not exclusive and there are several other possible mechanisms to explain the alpha-cell increased response in the restricted rats: basal alpha-cell hyperfunction could be caused by the direct effect of the low basal glucose level, and/or a decrease in the islet concentration of insulin and/or $\gamma$-aminobutyric acid (GABA), two agents which are potent inhibitors of glucagon release [29]. The finding of normal pancreatic somatostatin (SRIF) concentration in a similar protein-restricted rat model suggests that intrapancreatic SRIF is not involved in the enhanced alpha-cell response [30].

Our present hormonal findings help to interpret our previous report that the liver glucose production is increased in the basal postabsorptive state in the restricted rats [5]. However such a counterregulatory hormone pattern does not fit easily with the observation that total glucose utilization rate in the basal state is increased in the same rats [5], since it is generally accepted that catecholamines acutely decrease glucose utilization, either directly $[31,32]$ and/or indirectly by mobilization of non-esterified fatty acids [33]. One possible explanation for the difference in the glucose utilization responses may be related to differential impact of chronic compared to acute exposure to high catecholamine levels. There are studies in the literature which demonstrate that chronic elevation of norepinephrine [34] or epinephrine [35] improved the whole body glucose disposal as well as the insulin-stimulated glucose uptake in skeletal 
muscle. Despite the lack of knowledge concerning the mechanism by which chronic high catecholamine levels potentiate whole body glucose disposal, it is recognized that they play a crucial role in the improvement of glucose uptake by rat peripheral tissues after physical training [36], cold exposure [37] or ventromedial hypothalamic stimulation [38].

Another possible mechanism which may contribute to the increased total glucose utilization in the restricted rats, is the significant lowering of plasma growth hormone and corticosterone levels (by 59 and $32 \%$, respectively) as found in the basal postabsorptive state. Such an assumption is supported by the previous report that isolated lack of cortisol as well as growth hormone, caused a decrease in hepatic glucose production and an increase in glucose utilization with a resulting greater hypoglycaemia despite increase in plasma catecholamines [12,13]. Moreover it has also been shown that prolonged growth hormone deficiency results in increased sensitivity to insulin [39].

With respect to the responses to acute severe hypoglycaemia, the absolute plasma levels for glucagon, epinephrine and norepinephrine in restricted rats, were found to be not significantly different from those found in control rats. Accordingly the magnitude of the glucagon, epinephrine and norepinephrine responses to a calibrated hypoglycaemic stress $(\sim 2.5 \mathrm{mmol} / \mathrm{l})$ were found to be reduced in the restricted rats as compared to controls (by 32, 16 and $60 \%$, respectively). Also, the corticosterone response to acute hypoglycaemia was found to be blunted (by $79 \%$ ) as compared to the response in normal rats. However one must remain cautious when considering the significance of these data in terms of counterregulatory hormone response, since the amplitude of fall in glucose level was lower in the restricted group than in the control group. The plasma growth hormone response was not significantly induced by acute hypoglycaemia under our experimental conditions, neither in the restricted nor in the control rats.

While the role of the individual counterregulatory hormones in hypoglycaemia correction has been studied extensively, the mechanisms that link glucopenia with activation of the counterregulatory system are poorly understood. Both the central nervous system (CNS) and extracerebal glucose sensors have been implicated in the activation of counterregulatory hormone release during hypoglycaemia [14, 40, $41,44]$. It is therefore conceivable that protein-calorie restriction early in life alters CNS control of counterregulatory hormone release. Of course additional studies are warranted to test this hypothesis, but there are indications in the literature that protein deprivation significantly impairs a variety of neurotransmitter systems in the CNS including $\beta$-endorphin [45], norepinephrine [46], neuropeptide Y [47] and growth hormone-releasing factor (GRF) [48]. Concerning this last neuropeptide, it has been proposed that a reduction in hypothalamic GRF signalling to pituitary somatotrophs after dietary protein restriction is a major determinant of the suppression of the pulsatile growth hormone secretion $[30,49]$, with a resulting decreased basal plasma growth hormone level as confirmed in our present study.

In conclusion, the results of the present study demonstrate that protein-energy restriction in the rat: 1) alters the main circulating counterregulatory factors in the basal postabsorptive state, since the plasma levels of epinephrine, norepinephrine and glucagon are elevated and the plasma levels of growth hormone and corticosterone are blunted; 2) does not modify significantly the plasma levels of epinephrine, norepinephrine and glucagon in response to a severe hypoglycaemia $(2.5 \mathrm{mmol} / \mathrm{l})$ while plasma growth hormone and corticosterone levels remain significantly reduced. Our findings help to interpret the paradoxical metabolic pattern we previously reported in this model, i.e. increased hepatic glucose production together with increased overall glucose utilization. They also suggest that low protein diet acting from the weaning period, is an important modulator of the brain regions involved in the adaptation to hypoglycaemia.

A cknowledgements. This work was partly supported by a grant from the Ministère de l'Education Nationale, de l'Enseignement Supérieur et de la Recherche ( $n^{\circ}$ 95-G-0103; programme interministériel "Aliment Demain”).

\section{References}

1. Becker DJ (1971) The endocrine responses to protein calorie malnutrition. Annu Rev Nutr 3:187-212

2. Heard CRC (1978) The effects of protein-energy malnutrition on blood glucose homeostasis. World Rev Nutr Diet 30: 107-147

3. Okitolonda W, Brichard SM, Henquin JC (1987) Repercussions of chronic protein-calorie malnutrition on glucose homeostasis in the rat. Diabetologia 30: 946-951

4. Crace CJ, Swenne I, Kohn PG, Srain AJ, Milner RDG (1990) Protein-energy malnutrition induces changes in insulin sensitivity. Diabète Métab 16: 484-491

5. Picarel-Blanchot F, Alvarez C, Bailbé D, Pascual-Leone AM, Portha B (1995) Changes in insulin action and insulin secretion in the rat after dietary restriction early in life: influence of food restriction versus low-protein food restriction. Metabolism 44: 1519-1526

6. Escriva F, Rodriguez C, Cacho J, Alvarez C, Portha B, Pascual-Leone AM (1972) Glucose utilization and insulin action in adult rats submitted to prolonged food restriction. Am J Physiol 263:E1-E7

7. Gerich J, Cryer P, Rizza R (1980) Hormonal mechanisms in acute glucose counterregulation: the relative roles of glucagon, epinephrine, norepinephrine, growth hormone and cortisol. Metabolism 29: 1164-1175

8. Cryer PE (1993) Glucose counterregulation: prevention and correction of hypoglycemia in humans. Am J Physiol 264:E149-E155 
9. De Feo P, Perriello G, Torlone E et al. (1991) Contribution of adrenergic mechanisms to glucose counterregulation in humans. Am J Physiol 261:E725-E736

10. Rosen SG, Clutter WE, Berk MA, Shah SD, Cryer PE (1984) Epinephrine supports the postabsorptive plasma glucose concentration, and prevents hypoglycemia, when glucagon secretion is deficient in man. J Clin. Invest 73: 405-411

11. Boyle PJ, Cryer PE (1991) Growth hormone, cortisol, or both are involved in defense against, but are not critical to recovery form, hypoglycemia. Am J Physiol 260:E395-E402

12. De Feo P, Perriello G, Torlone E et al. (1989) Demonstration of a role for growth hormone in glucose counterregulation. Am J Physiol 256:E835-E843

13. De Feo P, Perriello G, Torlone E et al. (1989) Contribution of cortisol to glucose counterregulation in humans. Am J Physiol 257:E35-E42

14. Borg WP, During MJ, Sherwin RS, Borg MA, Brines ML, Shulman GI (1994) Ventromedial hypothalamic lesions in rats suppress counterregulatory responses to hypoglycemia. J Clin Invest 93: 1677-1682

15. Swenne I, Crace CJ, Milner RDG (1987) Persistent impairment of insulin secretory response to glucose in adult rats after limited period of protein-calorie malnutrition early in life. Diabetes 36: 454-458

16. Escriva F, Kergoat M, Bailbé D., Pascual-Leone AM, Portha B (1991) Increased insulin action in the rat after protein malnutrition early in life. Diabetologia 34: 559-564

17. Younoszai R, Dixit PK (1980) Decreased insulin secretion by isolated pancreatic islets from rats fed $4 \%$ protein diet. Proc Soc Exp Biol Med 164: 317-321

18. Levine LS, Wright PG, Marcus F (1983) Failure to secrete immunoreactive insulin by rats fed a low protein diet. Acta Endocrinol 102: 240-245

19. Swenne I, Borg LAH, Crace CJ, Schnell-Landström A (1992) Persistent reduction of pancreatic beta-cell mass after a limited period of protein-energy malnutrition in the young rat. Diabetologia 35: 939-945

20. Ashworth MA, Kerbel NC, Haist RE (1952) Effect of chronic caloric insufficiency on the growth of the islets of Langerhans. Am J Physiol 171: 25-28

21. Dixit PK, Kaung HLC (1985) Rat pancreatic B-cells in protein deficiency: a study involving morphometric analysis and alloxan effect. J Nutr 115: 375-381

22. Snoeck A, Remacle C, Reusens B, Hoet JJ (1990) Effects of a low protein diet during pregnancy on the fetal rat endocrine pancreas. Biol Neonate 5: 107-118

23. Woods SC, Porte D (1974) Neural control of the endocrine pancreas. Physiol Rev 54: 596-619

24. Miller RE (1981) Pancreatic neuroendocrinology: peripheral neural mechanisms in the regulation of the islets of Langerhans. Endocrine Rev 2: 471-494

25. Ahren B, Taborsky GJ Jr, Porte D Jr (1986) Neuropeptidergic versus cholinergic and adrenergic regulation of islet hormone secretion. Diabetologia 29: 827-836

26. Kenovian AV, Vander Tuig JG, Romsos DR (1984) Consumption of a low protein diet increases norepinephrine turnover in brown adipose tissue of adult rats. J Nutr 114: 543-549

27. Rothwell NJ, Stock MJ, Tizbir RS (1983) Mechanisms of thermogenesis induced by low protein diets. Metabolism 32: 257-261

28. Marichich ES, Molina VA, Orsingher OA (1979) Persistent changes in central catecholaminergic system after recovery of perinatally undernourished rats. J Nutr 109: 1045-1050

29. Samols E, Tyler J, Marks V (1972) Glucagon-insulin interrelationships. In: Lefébvre PJ, Unger RH (eds) Glucagon. Molecular physiology. Clinical and therapeutic implications. Pergamon, Oxford, pp. 151-173
30. Harel Z, Tannenbaum GS (1995) Long-term alterations in growth hormone and insulin secretion after temporary dietary protein restriction in early life in the rat. Pediatr Res 38: 747-753

31. Sacca L, Marrone G, Cicala M, Corso G, Ungaro B (1980) Influence of epinephrine, norepinephrine and isoproterenol on glucose homeostasis in normal man. J Clin Endocrinol Metab 50: 680-684

32. Rizza RA, Cryer PE, Haymond MW, Gerich JE (1980) Adrenergic mechanisms for the effect of epinephrine on glucose production and clearance in man. $\mathrm{J}$ Clin Invest 65 : 682-689

33. Fanelli C, De Feo P, Porcellati F et al. (1992) Adrenergic mechanisms contribute to hypoglycemic glucose counterregulation in man largely by accelerating lipolysis. J Clin Invest 89: 2005-2013

34. Lupien JR, Hirshman MF, Horton ES (1990) Effects of norephinephrine infusion on in vivo insulin sensitivity and responsiveness. Am J Physiol 259:E210-E215

35. Budohoski L, Challiss RAJ, Dubaniewicz A et al. (1984) Effects of prolonged elevation of plasma adrenaline concentration in vivo on insulin-sensitivity in soleus muscle of the rat. Biochem J 244: 655-660

36. Richter EA, Ploug T, Galbo H (1985) Increased muscle glucose uptake after exercise. No need for insulin during exercise. Diabetes 34: 1041-1048

37. Budohoski L, Challiss RAJ, Lozeman FJ, McManus B, Newsholme EA (1984) Increased insulin sensitivity in soleus muscle from cold-exposed rats: reversal by an adenosine-receptor agonist. FEBS Lett 175: 402-406

38. Sudo M, Minokoshi Y, Shimazu T (1991) Ventromedial hypothalamic stimulation enhances peripheral glucose uptake in anesthetized rats. Am J Physiol 261:E298-E303

39. Davidson MB (1987) Effect of growth hormone on carbohydrate and lipid metabolism. Endocr Rev 8: 115-131

40. Russek M (1963) Participation of hepatic glucoreceptors in the control of food intake. Nature 197: 79-80

41. Niijima A (1980) Glucose sensitive afferent nerve fibers in the liver and regulation of blood glucose. Brain Res Bull 5 [Suppl 4]:175-179

42. Biggers DW, Myers SR, Neal D et al. (1989) Role of brain in counterregulation of insulin-induced hypoglycemia in dogs. Diabetes 37: 7-16

43. Frizzel RT, Jones EM, Davis SN et al. (1993) Counterregulation during hypoglycemia is directed by widespread brain regions. Diabetes 42: 1253-1261

44. Borg WP, Sherwin RS, During MJ, Borg MA, Shulman GI (1995) Local ventromedial hypothalamus glucopenia triggers counterregulatory hormone release. Diabetes 44: 180-184

45. Vendite D, Rocha JBT, Souza DO (1988) Effects of undernutrition during suckling and of training on the hypothalamic $\beta$-endorphin of young and adult rats. Peptides 9: $751-755$

46. Vander Tuig JG, Beneke WM (1996) A low-protein diet blocks development of hyperphagia and obesity in rats with hypothalamic knife cuts. J Nutr 126: 1713-1721

47. White BD, Bin He, Dean RG, Martin RJ (1994) Low protein diets increase neuropeptide $\mathrm{Y}$ gene expression in the basomedial hypothalamus of rats. J Nutr 124: 1152-1160

48. Bruno JF, Song J, Berelowitz M (1991) Regulation of rat hypothalamic preprogrowth hormone-releasing factor messenger ribonucleic acid by dietary protein. Endocrinology 129: 1226-1232

49. Harel Z, Tannenbaum GS (1993) Dietary protein restriction impairs both spontaneous and growth hormone-releasing factor-stimulated growth hormone release in the rat. Endocrinology 133: 1035-1043 